\title{
Angles
}

New Perspectives on the Anglophone World

$6 \mid 2018$

Experimental Art

\section{Video introduction to issue 6}

Anne-Laure Fortin-Tournès, Brigitte Félix and Hélène Lecossois

\section{Q OpenEdition}

\section{Journals}

Electronic version

URL: https://journals.openedition.org/angles/953

DOI: 10.4000/angles.953

ISSN: 2274-2042

\section{Publisher}

Société des Anglicistes de l'Enseignement Supérieur

\section{Electronic reference}

Anne-Laure Fortin-Tournès, Brigitte Félix and Hélène Lecossois, "Video introduction to issue 6", Angles [Online], 6 | 2018, Online since 01 April 2018, connection on 16 June 2022. URL: http:// journals.openedition.org/angles/953; DOI: https://doi.org/10.4000/angles.953

This text was automatically generated on 16 June 2022.

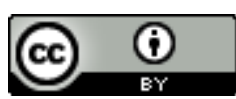

Angles est mise à disposition selon les termes de la Licence Creative Commons Attribution 4.0 International. 


\title{
Video introduction to issue 6
}

\author{
Anne-Laure Fortin-Tournès, Brigitte Félix and Hélène Lecossois
}

This media file cannot be displayed. Please refer to the online document http:// journals.openedition.org/angles/953

\section{Transcript:}

1 In their introduction to the 2005 issue of Tracés, dedicated to "Experimenting", Anthony Feneuil and Pierre Saint-Germier point out that contemporary aesthetics, like science shows an interest in the notion of experimentation. The idea of "experimental art" is the legacy of our modernity. But what if we consider, together with Derek Attridge in the article which opens this dossier, that "all art worthy of the name is experimental"? Then we need to examine more closely this experimental quality which seems to be such an essential part of the definition of art.

2 First of all, does "experimental art" as such exist or should we speak of an experimental dimension in art? In that case, the experimental dimension might be found in the creation of utterly new forms, but also in the renewal and the transgression of existing forms. The idea that a work of art is experimental stems from the apparent rejection of the previously dominant mimetic mode, but that is not necessarily the case: contents, not just forms, can be the site of an experimentation.

3 Although the $20^{\text {th }}$ and $21^{\text {st }}$ centuries are particularly rich in "experimental" fictions, from the start the novel has been characterized by its experimentation with the representation of the world. Let us remember the example of Laurence Sterne's Tristram Shandy with its black and marbled pages, or the sinuous line of a spiral to represent the plot on the page. From the moment of its invention to the contemporary openness of fictions overriding generic boundaries, the novel as a self-exploratory genre has fed on formal experiments.

4 Dealing with experimentation in the novel leads us to consider the materiality of the text. All the strategies of "form-breaking" come into play, which can include the incorporation of other media. The debate can therefore be extended to 
experimentation in the arts in general. Does the qualification "experimental" bring added value to the artistic gesture?

Those are some of the questions addressed by the seven articles gathered for this issue of Angles, the selection of photographs by Paul Edwards, and the interview with curator Philippe Riss-Schmidt.

In "What do we mean by experimental art?", Derek Attridge examines the acceptions of the adjective "experimental" in the hard sciences, then in its relations with innovation and avant-garde. Attridge proposes to replace the idea of experimentation, which is too indeterminate, by that of "invention" as conceptualized by Derrida. Inventiveness in art aims at revealing what is "excluded by the current cultural configuration" and thus opens "a path for future work".

7 In the collection of stories Bird Lovers, Backyard and in her recent novel Experimental Animals (A Reality Fiction), Thalia Field investigates the complexity of the links between experimental science and storytelling. As Abigail Lang shows, Field takes issue with the scientist view of science developed by Claude Bernard, which includes experimentation on animals. Field's texts develop an ethical poetics of experiencing - as opposed to experimenting - in which the artist's task is to deal with the chaotic nature of the world and of life.

R. M. Berry goes back to the Modernist moment of experimentation to probe the origins of the notion. The Modernist novels of Joyce, Woolf and Faulkner have undeniably established models of experimentation with narrative, but the legacy of those "models" has proven problematic for the experimenters of the fifties, sixties and seventies. Actually, the contemporary novel can be experimental on its own terms only if it works as "performative experiment" in which the readers' experience is engaged with the text.

9 The works of "high modernist" writers such as James Joyce or Ezra Pound were for a long time held as defining the very nature of the experimental in art. It now appears that works which have never been considered as part of the modernist canon are no less experimental. Why then have such novels as Virginia Woolf's Orlando or Djuna Barnes's Ladies Almanack never been regarded as experimental? This is the question Elaine Chou raises in "New Old Forms: Djuna Barnes's and Virginia Woolf's Return to the Archaic as Experimental Modernist Form".

10 Catherine Bernard looks into the way artistic experimentation has changed since the age of the avant-gardes while retaining its critical edge. The Tate Modern Unilever Series (2000-2012) is a perfect illustration of that change, as it explores corporeality and sensation in relation to the possibility of critical knowledge. Catherine Bernard's definition of experimentation as introducing tension between intellection and sensation leads her to show that artistic experimentation nowadays does not only seek to work the sensation regime imposed by the culture industry but is also critical of it.

11 Site-specificity and the search for new, original locations are largely responsible for the experimental quality of British art today. Charlotte Gould thus explores the ways in which experimental qualities are now disseminated over the whole process of imagining, producing and remembering works that are often ephemeral. The Artangel Trust that specialises in looking for unexpected sites to commission for ephemeral art is a case in point. Its hybrid model of financing has allowed the trust to resist the political instrumentalisation of art. 

of Belgian artist Marcel Broodthaers - his fictional museum project, "Musée d'art moderne, Département des Aigles" (1968-72) - as a paradigm of the experimental in the visual arts of the 1960s and 1970s.

13 with by contemporary curators like Philippe Riss-Schmidt, who presented HyperPavilion
at the $57^{\text {th }}$ Venice Biennial in 2017. In his interview with Anne-Laure Fortin-Tournès,
Philippe Riss-Schmidt comments on how contemporary art confronts the entanglement
of the digital with the physical in the age of posthumanism. To supplement our investigation of the experimental in art, academic and photographer Paul Edwards has kindly agreed to have a selection of his photographs included in the current issue of Angles. The photographs are Tarot card illustrations of Naomi's Mademoiselle de Phocas, a novel which originally appeared in the Ouphopo - the Workshop for Potential Photography - between 2005 and 2007 and which was translated into English by Paul Edwards himself.

\section{ABSTRACTS}

This video introduces the thematic contributions on 'Experimental Art'.

La vidéo présente les contributions thématiques sur "L'art expérimental".

\section{INDEX}

Keywords: video, art, experimental, literature, United Kingdom, Ireland, Great-Britain, United States

Mots-clés: vidéo, art, expérimental, littérature, Royaume-Uni, Irlande, Grande-Bretagne, ÉtatsUnis

\section{AUTHORS}

\section{ANNE-LAURE FORTIN-TOURNÈS}

Co-Guest editor of Issue 6. Professor at the Université du Mans.

\section{BRIGITTE FÉLIX}

Co-Guest editor of Issue 6. Professor at the Université Paris 8.

\section{HÉLÈNE LECOSSOIS}

Co-Guest editor of Issue 6. Professor at the Université Lille 3. 